\title{
Economic aspects of tobacco use and taxation policy
}

\author{
Christine Godfrey, Alan Maynard
}

Strong medical evidence about the adverse effects of tobacco use on health has been available for many decades, ${ }^{12}$ and as many as 100000 people probably die prematurely in Britain because of tobacco use. ${ }^{3}$ This paper examines the influence of economic variables such as price and income on tobacco consumption and sets out some of the attributes on the supply side of the tobacco industry. Such information is an essential ingredient in the policy debate where the benefits of this trade-employment, satisfaction of consumers, and profits-have to be traded off against the costs-a reduced duration and quality of life for many users of tobacco. The paper also analyses the effects of various options for tax policy on consumption and the industry.

\section{Demand for tobacco}

TRENDS IN CONSUMPTION

During the past 30 years the consumption of tobacco has peaked and during the past decade especially it has declined steadily. Table I gives details of consumption for nine years between 1956 and 1986. Although the time trends differ across the five different consumption indexes, downward movements can be seen across all these measures of consumption.

\section{ECONOMIC INFLUENCES ON TOBACCO CONSUMPTION}

Many economic factors influence the consumption of tobacco. Emphasising the impact of price alone on consumption should be avoided because many other powerful influences are at work. Three are income (or purchasing power), advertising, and health education. Many of the studies reviewed below are based on series of data that end in the late 1970s. More recent results are reported which, among other things, show that tobacco consumption may be more responsive to price than was assumed previously.

\section{Review of existing studies}

The first report of the Royal College of Physicians precipitated studies in which the factors that influence cigarette and tobacco use were investigated. The objective of many of the earlier studies ${ }^{j \times}$ was to compare the merits of tax increases and health education policies as means of reducing tobacco consumption. In later studies $^{\text {11" }}$ the effects of advertising on consumption were investigated. These last studies precipitated fierce controversy between the Advertising Association and the BMA about the empirical evidence.

In most of these studies multiple regression analysis of tobacco consumption per person over a variety of time periods was carried out. Table II compares the findings from different studies which show the effect of price on tobacco consumption. A price elasticity gives the predicted percentage change in consumption resulting from a $1 \%$ change in prices, with all other factors that influence behaviour held constant. The estimated price elasticities produced by previous studies vary from low values-for instance, in Atkinson and Skegg - to much higher estimates of about -1 in McGuinness and Cowling. ${ }^{9}$ Thus, for instance, the results sponsored by industry (Metra) show that in the long run a $10 \%$ increase in prices will reduce tobacco consumption by between $4 \cdot 2$ and $5 \cdot 4 \% .^{10}$

Estimates of income elasticities show much less variation: Atkinson and Skegg $0 \cdot 36^{6}$; Peto $0 \cdot 14$ to $0 \cdot 49^{8}$; McGuinness and Cowling 0.31 short term and 0.33 long term ${ }^{9}$; Witt and Pass $0 \cdot 13^{\prime \prime}$; Radfar 0.12 short term and $0 \cdot 19$ long term ${ }^{12}$; and the Treasury $0 \cdot 6 .{ }^{13}$ For instance, using McGuinness and Cowling's results, in the long run a $10 \%$ increase in income increases consumption by $3 \cdot 3 \%$ when all other influences are held constant.

Though it is common to estimate the effects of both income and price, in only a few studies was the impact of advertising on the consumption of tobacco considered. The empirical results on the size and significance of advertising have been mixed. For those studies in which an advertising variable is significant the advertising elasticity is usually about $0 \cdot 1$, so that if advertising was reduced by $10 \%$ then (other things being equal) consumption would be predicted to fall about $1 \% .^{91112}$ In a report commissioned by the industry, ${ }^{10}$ however, no significant evidence of an association between advertising and cigarette consumption was found. The data used by Metra $^{10}$ are not available to independent researchers.

Since the first and subsequent reports by the Royal College of Physicians ${ }^{3+}$ the importance of health education on tobacco consumption has been recognised. Different researchers have, however, used different approaches to incorporate these effects in their models. Some treat the effects as being permanent,
University of York, York YO1 5DD

Christine Godfrey, BA research fellow, Addiction Research Centre

Alan Mavnard, BPHIL, professor of economics

Correspondence to: Professor Maynard.
TABLE I-Yearly tobacco consumption per person for population aged 15 years and over for nine years between 1956 and $1986^{\star}$

\begin{tabular}{|c|c|c|c|c|c|c|c|c|c|}
\hline & 1956 & 1960 & 1965 & 1970 & 1975 & 1980 & 1984 & 1985 & 1986 \\
\hline Pounds (lbs) of tobacco sold & $6 \cdot 3$ & $6 \cdot 8$ & $6 \cdot 2$ & $5 \cdot 9$ & 5.9 & $5 \cdot 5$ & $4 \cdot 5$ & $4 \cdot 4$ & $4 \cdot 3$ \\
\hline Pounds (lbs of cigarettes sold & $5 \cdot 5$ & $5 \cdot 9$ & $5 \cdot 4$ & $5 \cdot 2$ & $5 \cdot 1$ & $4 \cdot 9$ & $4 \cdot 0$ & 3.9 & $3 \cdot 8$ \\
\hline Expenditure on tobacco at 1980 prices $(\mathfrak{f})$ & 120 & 124 & 122 & 122 & 123 & 110 & 87 & 84 & 81 \\
\hline Expenditure on cigarettes at 1980 prices ( $\mathcal{L}$ ) & 100 & 110 & 102 & 104 & 103 & 95 & 75 & 73 & 70 \\
\hline No of cigarettes sold & 2550 & 2750 & 2700 & 3000 & 3100 & 2750 & 2200 & 2140 & 2080 \\
\hline
\end{tabular}

* (One pound $=0 \cdot 45+\mathrm{kg}$.

Sources: Lee PN, ed. Statistics of smoking in the United Kingdom. 7th ed. London: Tobacco Research Council, 1976.

Tobacco Advisory Council fact sheets 1977-1986.

Central Statistical Office, UK National Accounts. (CSO blue book). London: HMSO (annual).

Central Statistical Office. Monthly digest of statistics. London: HMSO (monthly). 
while others model a process in which, after an initial impact, consumption gradually returns to its previous levels. For examples of alternative approaches see Sumner, Atkinson and Skegg," McGuinness and Cowling, ${ }^{4}$ and Witt and Pass." Using the latter approach, Atkinson and Skegg" estimated that the 1962 report from the Royal College of Physicians, ${ }^{+}$the 1965 television ban on the advertising of cigarettes, and the 1971 report from the Royal College of Physicians ${ }^{211}$ each reduced consumption by $5 \%$ but that this effect declined by $1 \%$ a year. In another approach health education is regarded as specifically offsetting the effectiveness of advertising."

Few of the results obtained in these studies were calculated by means of data that were published after 1975. There have, however, been large decreases in consumption and substantial changes in tobacco prices and disposable income since 1975 . In a 1986 working paper of the Addiction Research Centre, University of York, Godfrey used data for 1956-84 and employed a general model that included several models in published papers as special cases. Statistical tests were carried out to find the simplest model with assumptions that were consistent with the data. On the basis of this model Godfrey obtained an estimated price elasticity of -0.56 , which is larger than some of the estimates shown in table II but close to the Treasury's estimate of $-0 \cdot 5$. (The measure of consumption in Godfrey's study was the weight of tobacco in cigarettes per adult.)

TABLE II-Estimates of price elasticity

\begin{tabular}{|c|c|c|}
\hline Study & Data & Elasticities \\
\hline Russell $(1973)^{7}$ & 1946-71 yearly) & $-0.5 t 0-0.66$ \\
\hline Atkinson and Skegg $(1973)^{6}$ & $1951-70$ (vearly) & 0.0 (men) $;-0.35$ (women) \\
\hline Sumner $(1971)^{5}$ & 1955-68 (vearly and quarterly) & -0.8 \\
\hline $\operatorname{Peto}(1974)^{x}$ & $1951-70$ vearly & -0.37 to -0.64 (men) \\
\hline McGuinness and Cowling $(1975)^{\prime \prime}$ & 1957-68 quarterly & $\begin{array}{l}\text { Short term }-0.99 \\
\text { Long term }-1.05\end{array}$ \\
\hline Witt and Pass $(1981)^{11}$ & 1955-75 (vearly) & -0.32 \\
\hline Metra Consulting Group LAd $(1979)^{10}$ & 1958-78 (quarterly) & $\begin{array}{l}\text { Short term }-0.34 \text { to }-0.54 \\
\text { Long term }-0.42 \text { to }-0.54\end{array}$ \\
\hline $\operatorname{Radfar}(1985)^{12}$ & $1965-80$ (quarterly & $\begin{array}{l}\text { Short term }-0.23 \\
\text { Long term }-0.39\end{array}$ \\
\hline Treasury $(1980)^{13}$ & - & -0.5 \\
\hline
\end{tabular}

Another result from this model is that rather than returning to previous levels of consumption after the effect of the first health shock in 1962 demand fell continually at a rate of $3 \%$ a year. These estimates are used below to predict the effects of alternative tax policies. In unpublished work Godfrey reported the results of estimations using other data-for example, different consumption measures like those set out in table I-and found results that were generally significant but varied in magnitude (from -0.4 to -1.5 ).

The conclusion to be derived from the above results is that tobacco consumption can be manipulated by the use of economic policies which increase the price, raise the price to compensate for the effects of increased purchasing power (income), reduce advertising expenditures, and increase health education activities.

\section{LIMITATIONS OF THESE RESULTS}

The scope for improving the analysis of the demand side of the tobacco market is considerable. The results reported in the previous section are for aggregate data, and the results of the few studies of disaggregated data ${ }^{614}$ suggest that the effects of price and other variables may differ across subgroups. Thus it would be useful to know if price and advertising elasticities, for instance, varied among different age groups, social classes, and sexes. The lack of publicly available data is a constraint on this sort of work. While many of the relevant data are collected by the industry, they are not always available to researchers, and publicly available data-for in- stance, material collected biannually in the general household survey - cover only a few years.

Other issues need to be researched. For instance, smokers may respond differently to large price changes (publicly announced with health links emphasised) and such responses may, as $\mathrm{Leu}^{15}$ found, be related to nominal rather than real (inflation adjusted) prices. Also, the effects of price and other variables on consumption can be explored using cohort or longitudinal data. Such work in the United States ${ }^{14}$ suggests that teenagers may be more responsive to price changes than the general population, and similar work in the United Kingdom would be useful in informing policy debates.

\section{SUMMARY}

Different studies have given different estimates of the effects of price and other variables on tobacco consumption. These variations seem to arise from the ways in which models are specified and the type of data used. Clearly, the consumption of tobacco does respond to changes in price, income, advertising, and health education. Godfrey's preliminary, unpublished work on a general model suggests that tobacco consumption may be more sensitive to price (and tax) changes than was found in some of the earlier studies reported in table II. But even with the estimates available it is possible to predict only the effects of small changes in variables on consumption behaviour, and the impact of major shocks, such as banning advertising, are more difficult to predict.

\section{Supply of tobacco}

If the demand for tobacco is reduced further by the positive use of economic policies, especially pricing, the industry will alter greatly. These effects are often poorly understood by health lobbies and are shown up disproportionately by an industry that is inevitably seeking to maintain its activities and profits. We believe that although reduced expenditure on tobacco will cause unemployment in the tobacco industry, consumers will divert their spending to other sectors, so creating jobs elsewhere.

\section{STRUCTURE OF THE INDUSTRY}

In the UK three major producers control over $90 \%$ of the tobacco market. The leader is the Imperial Group, now owned by Hanson Trust, which has $44 \%$ of the market and includes W D and $\mathrm{H} \mathrm{O}$ Wills and market brands such as Woodbine, Embassy, and John Player Special. Gallaghers, owned by the American company American Brands, had 32\% of the market in 1984 and sell Benson and Hedges, Silk Cut, and Old Holborn. Rothmans have $15 \%$ of the market, sell Rothmans, Peter Stuyvesant, and Dunhill, and are jointly owned by Phillip Morris (US) and the South African Rembrandt Group. A fourth company, British American Tobacco, which is based in the UK, trades abroad, especially in the USA, Brazil, and Germany.

The overseas markets in which British American Tobacco trades are also dominated by large companies: Phillip Morris, R J Reynolds, the Loews Corporation, and Gulf and Western. Furthermore, the tobacco leaf used by all these companies is controlled by six international buyers. Thus not only do eight companies dominate world wide but there is also integration vertically from the stage of production and purchase of the leaf to its manufacture and retail sale.

In recent years these companies have diversified, buying interests in non-tobacco companies such as distribution, engineering, financial services, food, paper and packaging, printing, and retailing concerns, and some in the alcohol industry. 


\section{EMPLOYMENT}

Employment in the tobacco industry has declined appreciably in the past 10 years (table III). By 1986 , with only 16900 employed in producing tobacco, it was a small $(0.32 \%)$ part of the manufacturing sector in the UK. Further jobs, however, are created by the trade in tobacco outside the manufacturing sectorthat is, in distributing and retailing the commodity.

TABLE III-Employment in the British tobacco industry

\begin{tabular}{|c|c|c|c|c|}
\hline \multirow[b]{2}{*}{ Year } & \multicolumn{2}{|c|}{ Tobacco industry } & \multirow{2}{*}{$\begin{array}{c}1 \% \text { Of all } \\
\text { manufacturing } \\
\text { jobs }\end{array}$} & \multirow{2}{*}{$\begin{array}{c}\% \text { Of all } \\
\text { jobs }\end{array}$} \\
\hline & No (thousands) & $\%$ Women & & \\
\hline 1976 & 32.9 & 54 & 0.46 & $0 \cdot 15$ \\
\hline 1977 & $31 \cdot 5$ & 54 & 0.44 & 0.14 \\
\hline 1978 & $31 \cdot 2$ & 52 & 0.44 & 0.14 \\
\hline 1979 & $30 \cdot 4$ & 51 & 0.43 & 0.14 \\
\hline 1980 & $29 \cdot 5$ & 50 & 0.45 & 0.13 \\
\hline 1981 & $27 \cdot 1$ & 49 & $0 \cdot+6$ & $0 \cdot 13$ \\
\hline $1982^{\star}$ & $28 \cdot 5$ & 47 & 0.49 & 0.14 \\
\hline 1983 & 26.9 & 45 & 0.49 & 0.13 \\
\hline 1984 & $22 \cdot 0$ & 46 & $0 \cdot 41$ & 0.11 \\
\hline 1985 & $19 \cdot 8$ & 45 & 0.36 & 0.09 \\
\hline 1986 & 16.9 & 45 & 0.32 & 0.08 \\
\hline
\end{tabular}

*Introduction of 1980 Standard Industrial Classification with changes in the definitions of industry groups.

Source: Department of Employment. Department of Employment Gazette London: HMSO (monthly). Figures for June in each year.

Mackay and Edwards ${ }^{\text {it }}$ estimated that in all-manufacture, distribution, and retailing of tobacco-264000 jobs were attributable to activities associated with the tobacco industry in the UK in 1980 . This implies that for every direct job in the industry another 6.5 existed in other industries that were dependent on tobacco. While it is difficult to make such estimates this one appears to be high and unpublished work by Godfrey on employment in the alcohol and tobacco industries, using alternative assumptions and methods, yields estimates between 25200 and 188600 in 1984 .

Thus the direct and indirect effects on employment of tobacco consumption have declined but remain appreciable. If, however, expenditure on tobacco falls consumers are left with money to spend elsewhere. Thus if antismoking policies reduce employment in the tobacco industry jobs will be created in other sectors as a result of switches in consumer spending. The net effects on employment of an antismoking policy may be small.

\section{EXPORTS AND IMPORTS}

Importation of cigarettes increased rapidly during the 1980 s, and by 1986 nearly 14 million cigarettes were entering the market in the UK. Table IV shows the values of exports and imports for cigarettes and figures for the total tobacco trade. This shows a decline

TABLE IV-Value of tobacco trade 1971-86 in current prices

\begin{tabular}{|c|c|c|c|c|c|c|}
\hline \multirow[b]{2}{*}{ Year } & \multicolumn{3}{|c|}{ Cigarettes only } & \multicolumn{3}{|c|}{ Total tobacco trade manufactured and unmanufactured } \\
\hline & $\underset{\left(£ \times 10^{3}\right)}{\text { Imports }}$ & $\begin{array}{l}\text { Exports } \\
\left(\mathscr{E} \times 10^{2}\right)\end{array}$ & Imports:exports & $\underset{\left(£ \times 10^{3}\right)}{\text { Imports }}$ & $\begin{array}{l}\text { Exports } \\
\left(£ \times 10^{2}\right)\end{array}$ & Imports:exports \\
\hline 1971 & 1978 & 39908 & $0.05: 1$ & 108985 & 42778 & $2 \cdot 55: 1$ \\
\hline 1972 & 2169 & 42134 & $0 \cdot 05: 1$ & 121576 & +7982 & $2 \cdot 53: 1$ \\
\hline 1973 & 4048 & 51287 & $0 \cdot 08: 1$ & 153798 & 58125 & $2 \cdot 65: 1$ \\
\hline 1974 & 4277 & 60602 & $0 \cdot 07: 1$ & $185+31$ & 68882 & $2 \cdot 69: 1$ \\
\hline 1975 & 4589 & 94287 & $0.05: 1$ & 192013 & 106344 & $1 \cdot 81: 1$ \\
\hline 1976 & 8209 & 117247 & $0 \cdot 07: 1$ & 236590 & 133784 & $1 \cdot 77: 1$ \\
\hline 1977 & 8841 & 147786 & $0 \cdot 06: 1$ & 256114 & 169681 & $1.51: 1$ \\
\hline 1978 & 13525 & 170667 & $0.08: 1$ & $453+30$ & 278930 & 1.63:1 \\
\hline 1979 & 16665 & 210633 & $0 \cdot 08: 1$ & $350+23$ & 340997 & 1.03:1 \\
\hline 1980 & 26806 & 284016 & $0 \cdot 09: 1$ & 235014 & 307992 & $0 \cdot 76: 1$ \\
\hline 1981 & 23187 & 336829 & $0.07: 1$ & $269+63$ & 360059 & $0 \cdot 75: 1$ \\
\hline 1982 & 40747 & 359867 & $0 \cdot 11: 1$ & 309196 & 391426 & $0 \cdot 79: 1$ \\
\hline 1983 & 30867 & 398153 & $0 \cdot 08: 1$ & 344594 & 434976 & $0 \cdot 79: 1$ \\
\hline 1984 & 51378 & 375578 & $0 \cdot 14: 1$ & 407053 & 420896 & $0 \cdot 97: 1$ \\
\hline 1985 & 76478 & 418523 & $0 \cdot 18: 1$ & 386752 & 465369 & $0 \cdot 83: 1$ \\
\hline 1986 & 81619 & 356170 & $0 \cdot 23: 1$ & 338764 & 406271 & $0 \cdot 83: 1$ \\
\hline
\end{tabular}

Source: Department of Trade and Industry. ()verseas Trade Statistics of the UK. London: HMSO) (monthly) in imports of leaf (associated with reduced consumption) and high levels of exports in the 1980s as the UK companies sought profits from sales abroad.

CONCLUSION

The tobacco industry is an oligopoly-that is, there are few sellers-and production is concentrated in all activities: leaf purchasing, manufacture, and sale. In the UK the industry employs under 17000 people in direct manufacture in the tobacco trade. The trade (import and export) in tobacco changed in the 1980s and the balance of trade in tobacco goods has improved considerably since 1971. Clearly these flows, which sustain jobs at home and abroad, would be changed by positive antismoking policies.

Tax policy options and their effects on consumption and the industry

TAXATION OF TOBACCO

During the past decade the real (adjusted for inflation) price of cigarettes has fluctuated, the purchasing power of smokers has increased-for example, in terms of the number of cigarettes that can be bought by one hour's work - and taxation on tobacco as a share of total expenditure on tobacco products has increased (table V).

TABLE V-Relative prices of cigarettes

\begin{tabular}{|c|c|c|c|c|}
\hline \multirow[b]{2}{*}{ Year } & \multirow{2}{*}{$\begin{array}{l}\text { Real prices } \\
(1980=100)\end{array}$} & \multicolumn{2}{|c|}{$\begin{array}{l}\text { No of cigarettest that can be } \\
\text { bought by one hour's work }\end{array}$} & \multirow{2}{*}{$\begin{array}{c}\text { Tobacco taxation } \\
\text { as share of total } \\
\text { expenditure on } \\
\text { tobacco products }\end{array}$} \\
\hline & & Male manual & Female manual & \\
\hline 1957 & $113 \cdot 7$ & 25 & 16 & $72 \cdot 3$ \\
\hline 1960 & $115 \cdot 6$ & 29 & 17 & $71 \cdot 3$ \\
\hline 1962 & $120 \cdot 7$ & 29 & 18 & $70 \cdot 4$ \\
\hline 1965 & $127 \cdot 5$ & 29 & 17 & $69 \cdot 7$ \\
\hline 1967 & 122.0 & $33(39) 6$ & $20(20) \mathbb{S}$ & $68 \cdot 7$ \\
\hline 1970 & 120.5 & +4 & 26 & $67 \cdot 1$ \\
\hline 1972 & $107 \cdot 8$ & 54 & 32 & $64 \cdot 7$ \\
\hline 1975 & $104 \cdot 4$ & 58 & 39 & $64 \cdot 9$ \\
\hline 1977 & 113.8 & 64 & 45 & $69 \cdot 5$ \\
\hline 1978 & $102 \cdot 6$ & 64 & 46 & $67 \cdot 5$ \\
\hline 1979 & $99 \cdot 2$ & 71 & 49 & $69 \cdot 5$ \\
\hline 1980 & $100 \cdot 0$ & 67 & 47 & $69 \cdot 0$ \\
\hline 1981 & $110 \cdot 9$ & 61 & 42 & $70 \cdot 3$ \\
\hline 1982 & $118 \cdot 0$ & 59 & 40 & $73 \cdot 1$ \\
\hline 1983 & $119 \cdot 2$ & 60 & 41 & $73 \cdot 3$ \\
\hline 1984 & 125.8 & 56 & 39 & $73 \cdot 8$ \\
\hline 1985 & $131 \cdot 2$ & 56 & 39 & 74.9 \\
\hline 1986 & 140.0 & 54 & 38 & $75 \cdot 3$ \\
\hline
\end{tabular}

*Calculated by dividing current expenditure on cigarettes by expenditure on cigarettes valued at 1980 prices and the "all items" implicit price deflator. tMen and women manual workers' hourly earnings from the Department of Employment Gazette. Typical cigarette prices obtained from annual report of HM Customs and Excise and for 1956-67 relate to the typical price of a standard plain cigarette, for 1968-78 to a standard filter cigarette, and for 1979-85 to a typical king size cigarette.

$\ddagger$ Figures calculated from UK National Accounts, various years.

Gigures in parentheses were calculated using the price of a standard filter cigarette in 1967 for comparison with the 1968 figure. The 1978 typical prices for a standard filter and a king size cigarette were the same.

Sources: HM Customs and Fxcise. Report of the Commissioners of Her Majests Customs and tiveise. Iondon: HMSO (annual).

Majesty's Customs and Excise. London: HMSO (annual). Department of Emplos

Central Statistical Office. United Kingdom National Accounts (CSO) blue book). London: HMSO (annual)

Table VI gives details of tobacco taxation since 1980. The real price of cigarettes has increased but with no consistent pattern, and consumption declined each year but unevenly between 1980 and 1986. The taxation on cigarettes is a monetary amount per unit and an ad valorem element of $21 \%$. The monetary amount per unit needs constant uprating to maintain its real value if prices rise. The freedom of the government to control consumption in this way may, however, be circumscribed by European Community regulations.

TAX REVENUE ON TOBACCO

The real yield from taxation on tobacco peaked in 


\begin{tabular}{|c|c|c|c|c|}
\hline Year & $\begin{array}{l}\text { Typical price after } \\
\text { budget of } 20 \text { king size } \\
\text { cigarettes } \\
\text { (pence) }\end{array}$ & $\begin{array}{l}\text { Tax per cigarette } \\
\text { (including value } \\
\text { added tax) } \\
\text { (pence) }\end{array}$ & $\begin{array}{l}\text { Index of real duty } \\
\text { per cigarette } \\
(1980=100)\end{array}$ & $\begin{array}{c}\text { Change in } \\
\text { consumption in year } \\
\text { after budget } \\
(\%)\end{array}$ \\
\hline 1980 & 73 & $51 \cdot 6$ & $100 \cdot 0$ & $-3 \cdot 45$ \\
\hline $\begin{array}{l}1981 \\
\text { (Additional adjustment }\end{array}$ & 91 & $67 \cdot 1$ & $115 \cdot 5$ & $-10 \cdot 50$ \\
\hline in June) & 95 & $70 \cdot 5$ & & \\
\hline 1982 & 102 & $76 \cdot 1$ & $118 \cdot 6$ & -6.65 \\
\hline 1983 & 109 & 80.4 & $119 \cdot 9$ & $-0 \cdot 70$ \\
\hline 1984 & 123 & $91 \cdot 8$ & $130 \cdot 0$ & $-5 \cdot 31$ \\
\hline 1985 & 133 & $99 \cdot 2$ & 132.5 & $-2 \cdot 70$ \\
\hline 1986 & 148 & 111.6 & $149 \cdot 1$ & -2.78 \\
\hline
\end{tabular}

Sources: For columns 1, 2, and 3: HM Customs and Excise. Report of the Commissioners of Her Majesty's Customs and Excise. London: HMSO (annual).

Consumption figures are for tobacco expenditure by financial year in 1980 prices, taken from Central Statistical Office. United Kingdom National Accounts (CSO blue book). London: HMSO (annual)

1965 and by 1986 had fallen by $10 \%$. Table VII shows that the importance of this tax as a source of government revenue has also fallen rapidly to $12 \%$ of total expenditure tax yields and only $4 \%$ of total tax revenue. These yields are not small. For instance, in 1986-7 they were equivalent to about $4 \mathrm{p}$ on the basic rate of income tax or to raising value added tax from 15 to $20 \%$.

If cigarette consumption fell to very low levels government revenue would, of course, drop. But if this happened over a long period, as in the recent past, tax revenues could be recouped from other sources. If people do not consume tobacco they will demand other goods, pay taxes on them, and so augment government revenues.

\section{INCREASING TAXATION ON TOBACCO}

Effects on consumption and revenue

Because of the relatively low price elasticities it is possible to raise taxation appreciably and have some effects on consumption and positive effects on tax revenue. Table VIII shows the estimated effects of

TABLE VII-Importance of tobacco revenue

\begin{tabular}{|c|c|c|c|}
\hline Year & $\begin{array}{l}\text { Real tax yields }{ }^{\star} \text { (duty } \\
\text { and value added tax }) \\
(\text { fm) }\end{array}$ & $\begin{array}{c}\text { Tax yield as } \\
\text { percentage of all } \\
\text { government taxes on } \\
\text { expenditure }\end{array}$ & $\begin{array}{c}\text { Tax yield as } \\
\text { percentage of total } \\
\text { current government } \\
\text { revenue }\end{array}$ \\
\hline 1957 & 3823 & $28 \cdot 2$ & 11.8 \\
\hline 1960 & 4163 & $28 \cdot 7$ & 11.9 \\
\hline 1962 & 4192 & $26 \cdot 8$ & 10.6 \\
\hline 1965 & 4317 & $24 \cdot 0$ & 9.8 \\
\hline 1967 & 4224 & 21.4 & $8 \cdot 4$ \\
\hline 1970 & 4006 & 18.0 & $6 \cdot 4$ \\
\hline 1972 & 3511 & $16 \cdot 2$ & $5 \cdot 8$ \\
\hline 1975 & 3393 & 15.8 & 4.9 \\
\hline 1977 & 3633 & 16.6 & $5 \cdot 1$ \\
\hline 1978 & 3462 & $15 \cdot 2$ & 4.8 \\
\hline 1979 & 3422 & 13.5 & 4.5 \\
\hline 1980 & 3363 & $12 \cdot 7$ & $4 \cdot 2$ \\
\hline 1981 & 3557 & 12.6 & $4 \cdot 3$ \\
\hline 1982 & 3539 & $12 \cdot 3$ & $4 \cdot 2$ \\
\hline 1983 & 3586 & $12 \cdot 3$ & $4 \cdot 1$ \\
\hline 1984 & 3689 & $12 \cdot 4$ & $4 \cdot 1$ \\
\hline 1985 & 3786 & $12 \cdot 2$ & 4.0 \\
\hline 1986 & 3877 & 11.9 & $4 \cdot 1$ \\
\hline
\end{tabular}

^Deflated by the "all items" implicit price deflator.

Source: Central Statistical Office. United Kingdom National Aciounts (CSO blue book). London: HMSO (annual).

TABLE VIII-Year by year estimated changes in consumption

\begin{tabular}{|c|c|c|c|c|c|c|}
\hline \multirow[b]{2}{*}{ Year } & \multicolumn{2}{|c|}{$0 \%$ Yearly real price increases } & \multicolumn{2}{|c|}{$5 \%$ Yearly real price increases } & \multicolumn{2}{|c|}{$10 \%$ Yearly real price increases } \\
\hline & Consumption $\star$ & $\begin{array}{l}\text { Annual } \\
\% \text { change }\end{array}$ & Consumption ${ }^{\star}$ & $\begin{array}{l}\text { Annual } \\
\% \text { change }\end{array}$ & Consumption ${ }^{\star}$ & $\begin{array}{l}\text { Annual } \\
\% \text { change }\end{array}$ \\
\hline 1985 & $3 \cdot 76$ & & $3 \cdot 76$ & & $3 \cdot 76$ & \\
\hline 1986 & $3 \cdot 72$ & -0.99 & 3.62 & -3.65 & $3 \cdot 53$ & $-6 \cdot 13$ \\
\hline 1987 & $3 \cdot 68$ & -0.99 & $3 \cdot 49$ & $-3 \cdot 65$ & $3 \cdot 31$ & $-6 \cdot 13$ \\
\hline 1988 & 3.65 & -0.99 & $3 \cdot 36$ & -3.65 & $3 \cdot 11$ & $--6 \cdot 13$ \\
\hline 1989 & $3 \cdot 61$ & -0.99 & $3 \cdot 24$ & $-3 \cdot 65$ & 2.92 & $-6 \cdot 13$ \\
\hline 1990 & $3 \cdot 58$ & -0.99 & $3 \cdot 12$ & $-3 \cdot 65$ & $2 \cdot 74$ & $-6 \cdot 13$ \\
\hline
\end{tabular}

*Consumption measured in lbs weight of tobacco in cigarettes per head.

Source: Calculated from Godfrey's model, assuming growth of real income by $3 \%$ a year

alternative tax increases and these indicate that, even if real prices are only maintained, consumption will continue to fall owing to underlying health education shock effects. A $10 \%$ annual increase in real prices would cut consumption by over $6 \%$ each year and yield increases in tax income throughout the forecast period (table IX). All these predictions assume a (high) 3\% increase in real incomes throughout the period and are derived from Godfrey's model as described above. There is, however, much uncertainty when predicting the effects of sustained tobacco tax policy by means of a model estimated using figures relating to periods in which no such policy has been in force. The results are also sensitive to the price elasticity used.

TABLE IX-Estimated change in tobacco revenue from a vearly $10 \%$ increase in real price

\begin{tabular}{|c|c|c|}
\hline Year & Estimated revenue $(\mathfrak{f m} 1985$ & Yearly \% change \\
\hline 1986 & 5609 & +6.9 \\
\hline 1987 & 5990 & +6.8 \\
\hline 1988 & 6362 & $+6 \cdot 2$ \\
\hline 1989 & $67+3$ & $+6 \cdot 0$ \\
\hline 1990 & 7128 & +5.7 \\
\hline
\end{tabular}

Source: As table VIII. Revenue figures for 1985 from Central Statistical Office. United Kingdom National Accounts (CSO blue book). London: HMSO annual:

\section{Effects on production and employment}

Table $\mathrm{X}$ contains figures on the changes in production, consumption, and employment during 1980-5. There is no clear relation between these three series. Levels of employment and output in the tobacco industry are not determined only by domestic consumption. Exports are an important part of output, and technical changes have resulted in increases in productivity so that increases in output need not require increases in employment. The estimation of a simple model relating employment to the level of production and a time trend to take account of technical progress yields an employment elasticity of $0 \cdot 7$, so that a $10 \%$ fall in production would be predicted to result in a $7 \%$ fall in employment with technical progress reducing employment by a further $1 \%$ a year.

TABLE $\mathrm{x}$-Percentage vearly changes in tobacco production, consumption, and employment

\begin{tabular}{|c|c|c|c|}
\hline Year & Consumption ${ }^{\star}$ & Production & Employment \\
\hline 1980 & $-2 \cdot 0$ & $+2 \cdot 8$ & $-4 \cdot 3$ \\
\hline 1981 & $-10 \cdot 0$ & $-2 \cdot 8$ & $-6 \cdot 7$ \\
\hline 1982 & $-6 \cdot 8$ & $-6 \cdot 7$ & $-6 \cdot 6$ \\
\hline 1983 & $-0 \cdot 3$ & $-0 \cdot 3$ & $-4 \cdot 2$ \\
\hline 1984 & $-2 \cdot 6$ & -0.3 & -104 \\
\hline 1985 & -1.7 & $-8 \cdot 2$ & $-10 \cdot 5$ \\
\hline 1986 & -3.5 & $-10 \cdot 4$ & $-1+2$ \\
\hline
\end{tabular}

*Consumption measured as the number of cigarettes released for home consumption. For this table these figures were not deflated for population changes.

tTobacco production from index of output of the production industries. $\neq$ Employment in tobacco industry from the Census of Production which gives UK figures.

Sources: Central Statistical Office. Monthly Digest of Statistics. L ondon: HMSO (monthly)

Central Statistical Office. Annual Abstract of Statistics. London: HMSO (annual).

Business Statistics Office. Annual Census of Production. I.ondon: HMSO) (annual).

If the estimated employment elasticity of $0 \cdot 7$ is used and falls in consumption are assumed to translate fully into falls in production-that is, tobacco companies cannot increase exports-then a $10 \%$ increase in tax each year could be estimated to result in a fall of 3700 jobs in the British tobacco industry by 1990. Falls in employment in the tobacco industry, however, will be compensated by increased employment in other sectors as patterns of consumers' expenditure change. The net effect on employment will depend on the 
characteristics of the shifts in demand and the labour requirements associated with the two different sets of consumption.

\section{Effects on social class}

Levels of tobacco expenditure increase with gross household income. In the 1986 family expenditure survey the lowest quintile of the income distribution have an average tobacco expenditure of $£ 2.67$ per week while the highest quintile group spend £5.25. The poor, however, pay a larger proportion of their income (on average) in taxes on tobacco. The Central Statistical Office ${ }^{18}$ calculated that in 1985 taxes on tobacco were $5.3 \%$ of disposable income for the bottom quintile income group of non-retired households and $1 \cdot 2 \%$ for the top quintile. The effects of tax changes on different income and social class groups will vary if they have different price elasticities. In a 1983 unpublished paper concerned with analyses of gender and class differences in tobacco consumption Townsend obtained a higher price elasticity $(-1 \cdot 3)$ for the lower social class than for the higher social classes $(-0.54$ to $-0 \cdot 75) .{ }^{19}$ Also, Atkinson, Gomulka, and Stern (working paper 57 of the Economic and Social Science Research Council programme on taxation, incentives and the distribution of income, London School of Economics), using family expenditure survey data for 1970 to 1980 , estimated that if the price increased by $25 \%$ consumption for households headed by an unemployed man would fall by $16 \cdot 4 \%$, while for households headed by a professional owner-occupier the fall would be only $11.5 \%$. Thus in the absence of other changes increasing taxation might reduce the degree of regressivity. On the other hand, if the demand of the lower social classes for tobacco has become less price responsive since these studies were carried out then increasing taxation might increase regressivity.

\section{SUMMARY}

Tax levels have important effects on cigarette prices and tax revenues. Over 70 p of every $£$ spent on tobacco goes to the Chancellor of the Exchequer, yielding over $£ 5$ billion. But the value of tobacco tax revenues have generally fallen-by 1986 they were $10 \%$ lower than at their peak in 1965, and tobacco revenue is becoming a smaller proportion of total tax receipts.

The impact of a consistent increase in tobacco taxation is important in terms of reduced consumption (and harm to health) as well as in terms of reduced employment. Revenue may, however, increase in the short term. Finally, if the findings of Townsend ${ }^{19}$ and Atkinson et al (see above) still apply then the distributive effects of increased taxation on the poor might be less than is sometimes feared.

\section{Conclusions}

The impact of price (taxation) on the consumption of tobacco appears to be important and may be greater than suggested by studies using data from the 1970 s. It seems that, other things being equal, a $10 \%$ increase in taxation would cut tobacco consumption by $5-6 \%$.

The effects of income, advertising, and health education may also be important, and manipulating these variables will cut consumption. Reductions in consumption will lead to reduced mortality and morbidity, and the economic consequences of changing patterns of mortality and morbidity remain to be examined. As far as effects on tax revenue are concerned, increased taxation is likely to increase government tax revenues in the short run.

While reduced consumption will reduce employment in the tobacco industry, job creation resulting from a shift in consumption patterns (out of tobacco and to other goods and services) will offset these effects on employment and the net effects are unlikely to be as large as claimed by the tobacco industry.

The conclusion to be drawn is that the demand of tobacco is influenced greatly by economic factors and that simple economic analysis can illuminate usefully the supply characteristics of the tobacco industry.

This paper was commissioned by the Smoking Research Review Committee of the Medical Research Council. We thank Professor Julian Peto, Dr Ruth Porter, Professor Nicholas Wald, and other members of the MRC-SRRC for advice and constructive criticism during the preparation of the paper. We also thank them and Professor George Knox, $\mathrm{Mr}$ Roger Opie, and Professor Lord Peston for helpful comments on an earlier draft and Geoffrey Hardman for statistical help.

1 Wynder EL, Graham EA. Tobacco smoking as a possible etiologic factor in brochiogenic carcinoma. FAMA 1950;143:329.

Doll R, Hill AB. Mortality in relation to smoking: 10 years of observation of British doctors. Br Med f 1964;i: 1399, 1460

3 Royal College of Physicians. Health or smoking. London: Pitman, 1983.

4 Royal College of Physicians. Smoking and health. London: Pitman, 1962.

5 Sumner MT. Demand for tobacco in the UK. The Manchester School 1971;39:23-36

6 Atkinson AB, Skegg J. Anti-smoking publicity and the demand for tobacco in the UK. The Manchester School 1973;41:265-82.

7 Russell MA. Changes in cigarette price and consumption by men in Britain 1946-74. British fournal of Preventive and Social Medicine 1973;27:1-7.

8 Peto J. Price and consumption of cigarettes: a case study for intervention. British foumal of Preventive and Social Medicine 1974;28:241-5.

9 McGuinness T, Cowling K. Advertising and the aggregate demand for cigarettes. European Economic Review 1975:6:311-28

10 Metra Consulting Group Limited. The relationship between total cigarette advertising and total cigarette consumption in the UK. London: Metra Consulting Group Limited, 1979.

11 Witt SF, Pass CL. The effects of health warnings and advertising on the demand for cigarettes. Scottish Foumal of Political Economy 1981;28:86-91.

12 Radfar M. The effect of advertising on total consumption of cigarettes in the UK. European Economic Review 1985;85:225-31.

13 HM Treasury. The change in revenue from an indirect tax change. Economic Trends 1980 March:97-107.

14 Lewit EM, Coate D, Grossman M. The effects of government regulation on teenage smoking. Fournal of Law and Economics 1981;14:545-69.

15 Leu RE. Anti-smoking publicity, taxation and the demand for cigarettes. fournal of Health Economics 1984;3:101-16.

16 Mackay DI, Edwards RT. The UK obacco industry: it economic significance. Edinburgh: Peida, 1982.

17 Godfrey C, Powell M. Alcohol and tobacco taxation: barriers to a public health perspective. Quarterly fournal of Social Affairs 1985;1:329-53.

8 Central Statistical Office. The effects of taxes and benefits on household income in 1985. Economic Trends 1987;405:101-17.

9 Townsend J. Cigarette tax, economic welfare and social class patterns of smoking. Applied Economics 1987;19:355-65.

20 Royal College of Physicians. Smoking and health now. London: Pitman, 1971.

(Accepted 25 May 1988)

\section{Correction}

Un-health promotion: results of a survey of alcohol promotion on television

An error occurred in this paper by Dr Roger Barton and Ms Sally Godfrey (4 June, p 1593). Figure 2 incorrectly showed that all advertisements between 1600 and 1800 were promoting alcohol. The correct figure is given below.

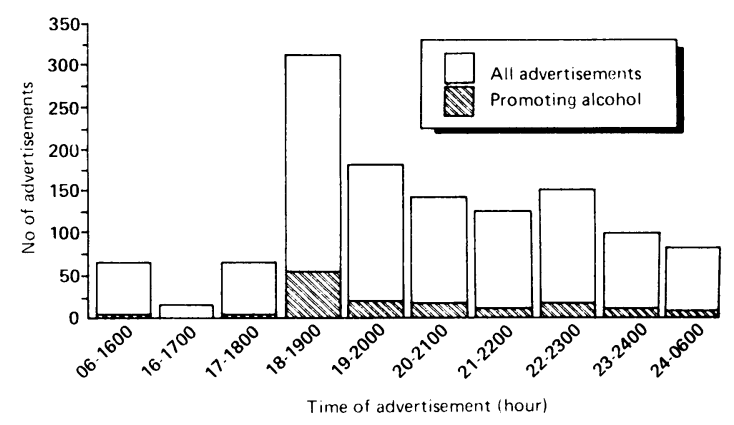

FIG 2-The numbers of advertisements recorded for each hour of the day. The increase in the number of advertisements promoting alcohol between the hours of 1800 and 1900 is notable 